\title{
Optimal Speed of Transition 10 Years After
}

\author{
by Tito Boeri, IGIER and CEPR
}

\section{Introduction}

When the transition was started there was no historical precedent to draw upon while making inferences on the future course of events. Educated guesses were allowed and were made, quite many of which turned out subsequently to be wrong. Knowledge evolves by comparing actual with expected outcomes and learning from these deviations. It is easy to be wise after the events. It is more difficult to understand why wrong predictions were made at the outset. This is the primary goal of this paper. From these predictions, the common wisdom prevailing at the beginning of the 1990s we need, in any event, to start.

There were three common predictions made at the outset of transition.

First, the removal of state subsidies and associated hardening of budget constraints would force many state enterprises to close down, inducing large scale labour shedding. In order to restructure these firms, rather than simply close down the shop, it was essential to win the strong resistance of workers to change, that is, to "buy them off".

Second, as a result of this shake-out striking at the core of "socialist employment", large inflows into unemployment of redundant workers would have to be expected. As the size of these inflows was related to the pace of closure of state enterprises, it was also argued that unemployment could be considered as an indicator of the determinacy of government to push through reforms and impose tough budget constraints on enterprises.

Third, unemployment would gradually be absorbed by the growth of the emerging sectors, namely private firms, mainly clustered in retail trade, the service sector or in light, final consumption goods, industries artificially compressed by central planning emphasis on primary accumulation.

In a nutshell, labour reallocation was deemed to occur mainly through unemployment, the single most important indicator of the speed of transition trajectories.

From a normative point of view, a careful timing of reforms was called for. Most of the models used to speculate on the future course of events yielded a multiplicity of equilibria and a non-trivial relation between the speed and final outcomes of transition. On the one hand, reforms had to be enforced in such a way as to avoid creating too much unemployment before a critical size of the private sector had been reached. Otherwise, social unrest related to increasing unemployment and 
the associated political backlashes of reformers, the fiscal burden induced by unemployment benefit payments or other "feedback" mechanisms (e.g., income effects of dis-employment) would block reforms. On the other hand, reforms could not be too slow as resources had to be freed for the growth of the private sector, unemployment had to start exerting its moderating effects on wage claims (and employers were deemed not sufficiently organised to resist such claims) and increased productivity had to stimulate investment. This was the essence of the trade-offs entailed by the models of the speed of transition developed at early stages of the process and widely used in policy advice throughout the region.

In this paper we will start by reviewing the extensive literature on the optimal speed of transition. Next, we will assess the empirical relevance and predictive accuracy of these models based on information on aggregate stocks and flows. The final section of this paper will list the various pieces of evidence left unexplained by this rich (and still flourishing) literature and argue that solving these puzzles is important in the light of the challenges facing these countries in the years to come. Thus, we will start by the theory and then go to the facts. The reader knowing the optimal speed literature can skip section 1.2 and go directly to the evidence presented in section 1.3.

\section{What did we expect to occur?}

When I first visited Warsaw at the beginning of January 1990, the policy-makers I met were largely underestimating the growth of unemployment. I distinctly remember that their estimates ranged from 50,000 (according to the most optimistic views, shared, inter alia, by the first Labour Minister of the new Poland) to 200,000 unemployed. Needless to say, at the end of that month, there were already 56,000 people registered unemployed in the Polish labour offices and the "pessimistic" 200,000 threshold was attained after just two months. One year later there were 1.2 million individuals registered unemployed. One-and-a-half years later the 2 million threshold had been crossed. Four years later about 3 million Polish citizens were registered as unemployed at labour offices.

The climate in the international organisations and within the scientific community was very different. The cross-country comparative view organisations like the IMF, OECD and World Bank, could draw upon and perhaps also the "distance" from which they could observe developments in the transition world dictated much less optimistic views as to the likely rise and magnitude of "transitional unemployment". The experience of eastern Germany was, after all, emblematic. Even if eastern German unemployment had been to a large extent a by-product of the political decision to fix a 1-to-1 parity of the eastern mark to the DM (and of the extension to the East of the western system of industrial relations ${ }^{1}$ ), these large cohorts of jobseekers were coming from enterprises often generating negative value-added and this evidence was even more striking as coming from the technological leader of the former CMEA (Council for Mutual Economic Assistance) block. Thus, there were many Cassandras around and ....I was among them.

Not only was unemployment considered inevitable, but it was also deemed to be an indicator of the speed of transition ${ }^{2}$. To a common way of thinking, there was a simple mechanics of transition. On the one hand, the removal of subsidies to state enterprises and their exposure to market discipline would force the managers of these firms to shed labour. On the other hand, a flourishing private

\footnotetext{
1 According to von Hagen (1997), the fact of exporting to eastern Germany western-type collective bargaining institutions reduced the competitivity of new Länders even more seriously than the exchange rate established at the time of unification.

${ }^{2}$ Cf. McAuley (1990).
} 
sector would generate employment opportunities in the numerous market areas (e.g., retail trade) and niches (central planning did not allow for product differentiation satisfying consumers' preferences for variety) artificially compressed under the old system. Thus, inflows into unemployment coming from the downscaling of state enterprises and outflows from unemployment associated with the emergence of the private sector were expected with the former exceeding the latter at earlier stages of transition because of the small scale of the private sector at the start of the process. Hence, unemployment would increase even if employment growth in the private sector was faster than job destruction in the state sector.

As an illustration of this scale effects, assume that a proportion "s" of employment in state enterprises $\left(E_{s}\right)$ is shed per period whilst in the meantime the private sector $\left(E_{p}\right)$ generates "g" new posts per any job existing at the beginning of the period. Thus, we have that:

(1) $\Delta U=I-O=s \cdot E_{s}-g \cdot E_{p}$

From (1) it follows that unemployment inflows (I) can exceed unemployment outflows $(\mathrm{O})$, hence unemployment can grow ( $\Delta U$ be positive) even if $\mathrm{g}$ is greater than $\mathrm{s}$, insofar as $\mathrm{E}_{\mathrm{p}}$ is small compared to $\mathrm{E}_{\mathrm{s}}$.

Put another way, unemployment was unavoidable at early stages of transition because even a buoyant private sector could not compensate employment losses in the overmanned state enterprises inherited from the previous system ${ }^{3}$. However, further down the transition path, i.e. for large $\mathrm{E}_{\mathrm{p}}$ and small $\mathrm{E}_{\mathrm{s}}$, unemployment would have to decline because the scale effects would begin to work the other way round. Overall, a hump-shaped dynamics of unemployment was expected, with unemployment initially increasing and then declining.

Unemployment was also deemed to be an indicator of the speed of reforms: inflows into unemployment were determined solely by the parameter "s", capturing the pace of labour shedding in state enterprises and hence the timing of removal of state subsidies and, more broadly, the tightening of the budget constraints of state enterprises.

Although unemployment was unavoidable, governments could at least prevent too large an initial rise in the number of jobless people, by fine-tuning employment reductions in state enterprises with the absorption capacity of the emerging private sector. However, the slowing down of restructuring in state enterprises could negatively affect the development of the private sector, by preventing excess labour from exerting downward pressure on wages and possibly via fiscal displacement effects related to the financing of subsidies to state enterprises.

\footnotetext{
${ }^{3}$ Several estimates were provided at the beginning of transition of the amount of "labour hoarding" (e.g., see OECD, 1994), that is employment kept in excess of what needed to attain the targeted output level. Most of these estimates were just guesses as there were no time-series of employment under different cyclical conditions or ad-hoc surveys to draw upon. The estimates pointed to overmanning accounting between 30 and 60 per cent of state sector employment at the beginning of the 1990s. Interestingly, the reduction of labour hoarding was considered by many eastern economists as the single most important sign of "marketisation" as if i) restructuring had involved only cost-minimisation, ii) firms also in the West, particularly in downturns, were not keeping workers in excess to the extent needed to reach a given level of output, and iii) reducing overmanning could be always crucial, e.g., even in countries and time-periods when real wages were falling dramatically.
} 


\subsection{Fine-tuning the speed of transition}

These interactions between "s" and "g", and policy trade-offs between the tightening of the budget constraints of state enterprises, unemployment and the development of the private sector are at the core of the theoretical literature on the optimal speed of transition (OST for short), which offered relevant background material for policy advice throughout the region. As the building blocks and main implications of the various models are reviewed in the annex, we can confine ourselves herein to summarising the key findings of this literature and the basic assumptions it relies upon.

A common feature of these models is the assumption that labour supply is fixed, i.e. persons are either employed ( $\mathrm{E}$ with the subscripts $\mathrm{s}$ and $\mathrm{p}$ denoting, respectively, state and private firms) or unemployed (U). In other words, labour market adjustment does not involve flows to and from outof-the-labour force (OLF). Another key simplifying assumption is that flows from public sector to private sector employment are necessarily mediated by intervening unemployment spells, that is no direct shift of workers from state to private enterprises occurs. The kind of flows allowed and "banned" under this literature are summarised in Figure 1.

This literature also considers the speed of closure of state sector jobs, labelled by s, as a control variable. Governments can affect labour shedding in state enterprises in various ways, e.g., by granting them subsidies, and by imposing strict employment protection legislation (e.g., nonnegligible severance and advance notification requirements on firms implementing layoffs). The other key policy variable is the generosity of unemployment benefits (summarised by the ratio of benefits to the ongoing wage or "replacement rate", b) provided to those displaced in transition. Governments can manipulate parameters "s" and "b" within their budget constraint. The latter is generally assumed to be static, that is, no deficit financing is allowed. Only the model by Coricelli (1996) allows for intertemporal budget constraints.

All these models aim at capturing institutional features of transitional economies, such as the important role played by workers in decision-making in state enterprises, and typically generate unemployment even at the steady state equilibrium. Although the micro-foundations of these models are not spelled out, reference is occasionally made to two sources of involuntary unemployment, namely the presence of moral hazard, e.g. associated with imperfect monitoring of workers' effort, or adverse selection, e.g. because of poor signals as to workers' actual productivity, both leading employers in the private sector to set wages above the market clearing level (efficiency wages). Frictions in the labour market making it more costly and time-consuming to reallocate workers from the state sector to the private sector are also framed, notably in the models by Burda (1993) and Gavin (1993). Thus, the literature departs from the standard assumptions and the basic setup of neoclassical growth theory. The price of this greater realism is that models are very rich in structural assumptions and it is more difficult to disentangle the role played by each market imperfection and to identify what drives labour market dynamics. The OST literature also follows, more or less admittedly ${ }^{4}$, a partial equilibrium approach, the main exception being in this case the general equilibrium model by Castanheira and Roland (1998) which is also an attempt to bridge the gap between these models and standard growth theory.

The policy trade-offs involved in the transition process are embedded in these models in a number of feedback mechanisms: unemployment growth is, on the one hand, influenced by the speed of the removal of state subsidies, but, on the other hand, high unemployment may strike back on speed because of fiscal effects related to the funding of unemployment benefits, political economy factors eroding the consensus gathered around the reform effort or other mechanisms.

\footnotetext{
${ }^{4}$ Even if ad hoc assumptions allow some authors to claim that these are general equilibrium models, their setup is a partial equilibrium one.
} 
In the seminal model by Aghion and Blanchard (1994) the basic feedback mechanism is one coming from the fiscal side: high unemployment means large outlays to fund unemployment benefits (as supposedly subsidising overmanning in state enterprises is costless while paying people out of work is $\operatorname{not}^{5}$ ), hence higher payroll taxation. This in turn reduces job creation in the private sector. This "fiscal externality" is at work also in the models by Burda (1993) and by Chadha and Coricelli (1994). The latter, unlike Aghion and Blanchard, allow for differential taxation of state and private enterprises. In particular, effective tax rates are assumed to be higher in the state than in the private sector owing to problems in revenue collection faced when dealing with private (and small) business. Hence, on Chadha and Coricelli's model, the fiscal balance deteriorates in the transition process even when unemployment is stable because an increasing proportion of the total wage bill of the economy is being paid by private employers ${ }^{6}$.

Another class of models identifies potential feedback mechanisms in political economy factors ${ }^{7}$. This is the case of the frameworks proposed, inter alia, by Przeworski (1993), Rodrik (1995) and Dewatripont and Roland (1992 and 1995). Rodrik's model shows that the window of opportunities existing at the outset of transition ${ }^{8}$ rapidly erodes as workers in state enterprises find it more and more difficult to shift to the emerging private sector and hence vote against further cuts to subsidies to state enterprises (which are, counterfactually, supposed to be entirely financed via taxation of private enterprises). In Dewatripont and Roland (1992), a big-bang reform strategy is bound to be stopped under majority rule. The only way to enact reforms is to introduce them gradually using divide-and-rule tactics whereby only the workers hurt by each reform will oppose it ${ }^{9}$. Divide-andrule tactics are also essential to start restructuring firms whose workers exert substantial control over managerial decisions. Under these circumstances, a sharp initial rise of unemployment may block reforms. If unemployment increases too much at the outset of transition, workers will oppose restructuring as they face low re-employment probabilities in the case of job loss (Blanchard, 1997). Intuitively, the job finding probability is given by outflows from unemployment over the unemployment stock, and high unemployment means a large "denominator" per any given absorption capacity of the private sector, that is per any given numerator.

\footnotetext{
${ }^{5}$ In this model subsidies to state enterprises come from Heaven. Subsidies to state enterprises are simply a policy instrument governments can freely adjust - that is, without taking resources away from other public expenditure items - in order to affect the speed of transition.

${ }^{6}$ The model by Castanheira and Roland (1998) does not have such a feedback mechanism. However, a too fast process of sectoral reallocation of workers can still end up perversely slowing down the transition process and generates mass unemployment because the (negative) income effects associated with plant closures dominate the (positive) substitution effects of wage declines induced by increasing unemployment.

${ }^{7}$ To be fair, political economy considerations are present also in the model by Aghion and Blanchard (1994). As spelled out in a subsequent work by Blanchard (1997), the generosity of unemployment benefits plays a key role in allowing worker-controlled state enterprises to begin (strategic) restructuring. However, the political economy of reforms -- notably industrial relations within the enterprise -- matters in these models only insofar as it hastens or postpones the restructuring of state enterprises. In other words, poltical economy factors do not play the role of a feedback mechanism potentially reversing the process once this has started.

${ }^{8}$ This window of opportunity is present also in the case of strategic voting when state enterprises are highly inefficient at the outset of transition. Even by initially voting against the reforms, state sector workers colud not prevent the median voter (whose preferences ultimately drive policy decisions) from getting out of the state sector. Moreover, if state sector workers succeed in shifting to the private sector, they will have to bear the burden of the subsidy they initially voted for. As long as private sector workers and the unemployed always vote against the subsidy, however, strategic voting rules out the possibility of policy reversals.

${ }^{9}$ This applies also when workers are forward-looking provided that the "old" sectors (e.g., state enterprises and cooperatives) are bound to disappear at some finite date. This is not the case in some OST models. For instance, in Rodrik's (1995) model, the state sector is supposed to survive even at the steady state equilibrium in spite of persistent productivity (and wage) differentials vis-à-vis the private sector.
} 
The presence of such feedback mechanisms opens up the possibility of a multiplicity of equilibria. This may be a desirable property of these models insofar as they aim also at explaining crosscountry differences in the levels at which unemployment is stabilising throughout central and eastern Europe and the former Soviet Republics. For instance, in Aghion and Blanchard's (1994) model, depending on the expectations of private sector employers, the economy may end up at a low unemployment equilibrium or the transition may fail, leading the economy to be trapped in a high unemployment equilibrium. Expectations matter because private employers decide on hirings on the basis of their assessment of their lifetime tax liabilities. Expectations are self-fulfilling as pessimistic private employers end up paying more taxes: they absorb workers shed by state enterprises too slowly, and hence have to pay more for unemployment benefits. A credible ${ }^{10}$ commitment by governments to reduce unemployment benefits (or to slow down restructuring in state enterprises) when unemployment is too high can prevent the occurrence of the high unemployment equilibrium.

\subsection{Policy implications of the OST literature}

Multiple equilibria and non-linearities in the adjustment paths point to the role of economic policies in ruling out "bad" equilibria", easing transition and reducing the risk of derailments. Thus, the OST literature has relevant policy implications as to i) the magnitude and timing of reduction of subsidies to state enterprises, ii) the generosity of unemployment benefits, iii) the form and speed of privatisation, and iv) the scope for deficit financing of social policies in the course of transition.

Although all models imply that subsidies to state enterprises will sooner or later have to be lifted, the OST literature suggests that there is a careful timing to be followed in the tightening of the budget constraints of state enterprises: too quick a reduction of subsidies means too large an initial rise of unemployment and associated fiscal burden (and/or income effects), hindering the growth of the private sector. Hence, subsidies have some role to play at the outset of transition. In other words, the OST literature makes a case for gradualism in spite of the fact that two key factors generally moving the balance in favour of gradualism vs. big-bang ${ }^{12}-$ the presence of a political learning process, and the possibility of early reversals -- are not embedded in these models.

Unemployment benefits play a twofold role in these models. On the one hand, insofar as they increase the value of the outside option of state sector workers, they ease ${ }^{13}$ the restructuring of state enterprises by reducing the opposition of insiders to employment reductions and to privatisation. On the other hand, the financing of unemployment benefits puts a brake on private employment creation and hence reduces its capacity to absorb labour shed from state enterprises. Owing to this trade-off between the effects of benefits on restructuring and on private job creation, unemployment benefits should be rather generous at the start of transition and then reduced (actually, in order to

\footnotetext{
${ }^{10}$ The announcement that benefits will be reduced if unemployment becomes too high may not be credible ex-ante. However, governments in the region proved capable of significantly tightening up unemployment benefits when unemployment was at its transitional peaks.

${ }^{11}$ High and low unemployment need not necessarily be synonymous in these models with "good" and "bad" equilibria, respectively. For example, in the model by Chadha et al. (1993), the economy may get trapped in a low unemployment equilibrium dominated by state firms, where no accumulation of physical and human capital takes place.

${ }^{12}$ The literature on gradualism vs. big-bang is reviewed in Dewatripont and Roland (1997).

${ }^{13}$ However, higher unemployment benefits negatively affect job finding probabilities of the unemployed by putting a higher floor to wage bargaining in the private sector, which means lower job creation. If individuals place a relatively high value on future consumption (if they have a rather low discount rate), the negative effect of higher benefits on unemployment outflows may offset the positive effect on the instantaneous value of being unemployed. See Annex 1 for a characterisation of these two mutually offsetting effects.
} 
rule out bad equilibria, governments should from the beginning commit themselves to reduce benefits if unemployment reaches a certain threshold). As shown by Blanchard (1997), later on, when unemployment is large, the "fiscal externality" tends to dominate. At that stage, a case for high benefits can only be made on equity grounds. This holds even when unemployment benefits are also meant to promote better matches between jobseekers and vacancies. Insofar as individuals are not very risk-adverse (hence the provision of insurance does not significantly affect voluntary decisions to undertake risky job search) and have a large precautionary demand for savings, also unemployment benefits aimed at promoting better matches ultimately slow down restructuring [Atkeson and Kehoe, 1993].

The choice among different privatisation rules is framed in these models as a change in the proportion of post-privatisation profits going to insiders [Aghion and Blanchard, 1996], which is zero in the case of pure outsider privatisation. More generous privatisation rules (an insider share close to one unit) reduce the opposition of insiders to restructuring by increasing the benefits they can get if they do not lose their job in the process. Unlike unemployment benefits, insider privatisation rules do not involve fiscal externalities (do not increase taxes paid by private enterprises), and hence do not exert negative feedback effects on the reallocation process. More important still, insider privatisation tends to reduce wage claims in the private sector -- as now workers involved in privatisation receive a share of firms' profits -- and may stimulate job creation $^{14}$. Hence, these models generally argue in favour of insider privatisation, a case against this method being made mainly on distributional grounds (as insider privatisation makes everybody worse off except those who happen to be employed in privatised firms).

Finally, debt-financing of social insurance is generally advocated by these models insofar as it allows offsetting of the feedback effects associated with the initial rise of unemployment. Excessively strict borrowing constraints - e.g., established in the context of macroeconomic stabilisation packages - may therefore have a negative effect on the pace of job reallocation and even jeopardise the success of economic transformation [Chadha and Coricelli, 1994]. Yet, the kind of foreign borrowing which is allowed in these models is a foreign transfer not involving future repayment obligations: more than foreign borrowing, it should be called a gift aimed at offsetting the fiscal externality effects associated with the rise of unemployment.

Summarising, a key assumption of the OST literature is that labour supply is fixed: one can be either employed or seeking a job. Inactivity is banned. In the light of this assumption, the many variants of the basic Harris-Todaro-type model which have been developed by this literature all consider the rate of decline of state sector jobs, s, as something that can be altered at will by governments. The control over $\mathrm{s}$ is both direct - insofar as governments decide upon the amount of subsidies to be granted to state enterprises - and indirect - because workers controlling state enterprises can be induced to accept restructuring plans by more generous unemployment benefits. Unemployment benefits themselves should be relatively generous at the start of transition, in order to set in motion the reallocation process, but governments should be committed to reduce the generosity of benefits when unemployment is above a certain threshold. Because of the heavy fiscal burden imposed by the financing of these benefits on private job creation, employers need to be convinced that transition will not eventually derail.

\footnotetext{
${ }^{14}$ These models underplay (if they at all consider them) the effects of different privatisation rules on enterprise behaviour via changes in corporate governance and managerial incentives. Hence, they neglect a possible feedback effect of insider privatisation on restructuring.
} 


\section{What Happened?}

\subsection{The output collapse}

All transition countries experienced after the beginning of the systemic transformation one of the deepest depressions ever observed in modern history. In the first two years of transition, GDP declined between 15 and 20 per cent (Figure 2., top panel). Output declines affected all sectors, but were particularly marked in industry. Gross industrial production fell everywhere more sharply than output and in Bulgaria and Romania industrial output halved between 1990 and 1992. The "transitional recession" was not less dramatic than the Great Depression. Actually, output declines were sharper and, at least for the Commonwealth of Independent States (CIS) countries, more protracted than in the US in the 1930s (Figure 2, bottom panel).

The transitional recession is often characterised as a U-shaped evolution of output. However, this is true only for the Central European countries, and yet some of them were at the end of 1998 still lagging behind the GDP levels of the previous decade. Eastern Europe, after a short recovery, experienced a new marked decline of GDP six to eight years down the road of transition. In the CIS countries the recession had not reached an end eight years after the beginning of the systemic transformation. Acknowledging measurement errors in economies largely de-monetised like those of the CIS, recorded GDP levels in this region were in 1998 still at about 50 per cent of the pretransition levels and the letter which could best describe the evolution of output is a L rather than a U.

The OST literature did not predict such a marked decline of output. And, after all, there was no reason to believe, a priori, that the transition from a less efficient to a more efficient production system should have involved dramatic falls in output. Also from an empirical standpoint, labour and capital reallocation costs involved by structural change could not be expected a priori to generate sizeable output losses. The empirical relation between structural change and output observed in OECD countries - the so-called Lilien's hypothesis ${ }^{15}$ - cannot yield comparable falls in output and output losses were, in any event, initially uniform across the board.

While a number of statistical issues (some over-reporting of output under the previous regime, changes in the composition of output and in the availability of goods to consumers that may not be captured by official statistics, a large hidden economy, etc.) could contribute to explain some of the GDP decline, the size of output losses could by no means reflect mere measurement problems.

Some explanations for the output losses were only provided ex-post - externally with respect to the OST literature ${ }^{16}$-- and were, for the most, not entirely convincing. The most ingenious interpretation is that provided Blanchard and Kremer (1997). They point to the dis-organisation in the production network, notably in the provision of materials and intermediate inputs, associated with the removal of central planning, the unbundling of the vertically integrated conglomerates inherited from the previous regime and rent-seeking behaviour on the part of input providers as soon as the coercive power of central planning (in enforcing the production and delivery of intermediate goods) ceased to exist. Under asymmetric information as to the reservation price of input providers or incomplete contracts, bargaining over input provision is inefficient and may lead

\footnotetext{
${ }^{15}$ Cf. Lilien (1982).

${ }^{16}$ The only explanation for the output fall provided within the OST literature is associated with the work of Atkeson and Kehoe (1995) who point to labour market frictions associated with sectoral shifts. Yet output fall was experienced unformly across the board and preceded sectoral shifts in employment. For earlier explanations of the output fall, see Gomulka (1992), Kornai (1993) and Wei Li (1994).
} 
to a collapse of production in the state sector. At any stage along the chain of production, the input provider may indeed find it more advantageous to break the chain. These problems arising from the interlocking of firms along the vertical links of production are bound to become less and less important as transition proceeds insofar as rents induce the multiplication of suppliers and hence the firm uphill in the production chain can always shift supplier. Thus, this explanation can only hold for the initial stages of transition. Based on measures of the "complexity of production" (capturing the number of intermediate inputs required by final goods in any given sector) obtained from inputoutput tables as well as business surveys reporting shortages of materials and intermediate inputs, Blanchard and Kremer find some support for the theory in Eastern Europe and the CIS ${ }^{17}$. Needless to say, in these countries output falls were much more protracted than implied by a transient disorganisational shock. Moreover Blanchard and Kremer's model is based on two key assumption for which there still little, if any, empirical support: the presence of Leontief-type technologies, that is, technologies not allowing to replace inputs being temporarily under-provided and a marked specificity of the inputs required by the firms inherited from the previous regime. Especially the latter assumption may sound somewhat unrealistic for firms which were frequently subject under the previous system to input shortages and in a context where production was still largely involving homogeneous goods and using inputs which were much less specific or specialised that in market economies. Surveys of enterprises carried out in these countries suggest that mainly new firms, producing new products find it difficult to secure domestically an adequate provision of intermediate goods and often have to use imported inputs ${ }^{18}$.

The explanation for the output fall provided by Roland and Verdier (1997) differs only slightly from that of Blanchard and Kremer. Unlike the latter, Roland and Verdier emphasise the existence of frictions in the search of new partners down the chain of production and relation-specific investment: firms do not invest until a long-term partner has not been found. Thus output fall in their model arises not only because of the disruption of previous production links, but also because of a fall in investment and the depreciation of capital associated with the absence of replacement investment. Many of the points made concerning the empirical relevance of Blanchard and Kremer's apply also to this model.

\subsection{Behind the stocks}

For quite some time labour market developments in these countries seemed to closely conform to a priori expectations and to the predictions of the models summarised in the previous section. Employment in state enterprises was plummeting, unemployment skyrocketing and private employment growing rapidly. Projecting over time the monthly growth rates of public and private employment experienced in 1989-91 by Poland - the first country to embark on a comprehensive structural transformation cum stabilisation process - and imposing, as customary in the OST literature, a constant labour force, one obtains the bell-shaped pattern of unemployment displayed in Figure 3, which bears a close resemblance to the evolutions implied by the models reviewed in the previous section. Unemployment is initially rising, reaches two-digits levels and then in vanishes as quickly as it appeared: we have the predicted (and quite reassuring) bell-shaped evolution of unemployment. Everything seemed to be working in line with expectations.

\footnotetext{
${ }^{17}$ Based on data from enterprise surveys in the Ukraine and Russia Konings and Walsh (1999) found little support to the role played by dis-organisation in the output fall in these two countries.

${ }^{18}$ See Koenings and Walsh (1999).
} 
However, a closer scrutiny of labour market dynamics and access to flow data soon revealed [Boeri, 1994] that the adjustment of labour markets in CEE was very different from what was predicted by these models and anticipated in most policy fora and academic discussions.

While employment reductions were expected to be driven by layoffs, data on separations from state enterprises indicate that a significant component of outflows from state sector jobs was associated with voluntary quits. Available evidence from Labour Force Survey (LFS) data (reported in the top panel of Table 1), points to rather large ratios of job leavers (persons currently non-employed because they had quit their previous job) to total employment and to shares of job losers (persons currently non-employed because they were laid-off from their previous job) roughly comparable to those observed in the European Union. Quite strikingly, in Poland and the Czech Republic the ratio of job losers to total employment was even lower than in Italy, the OECD country located at the top of rankings of employment protection against dismissals ${ }^{19}$ and experiencing among the lowest layoff rates in Western Europe. It should be stressed that the LFS questionnaire asks about the nature of the separation only those currently non-employed and many quits are likely to end up in the take-up of another job rather than in non-employment. Hence the data reported in Table 1. are likely to significantly underestimate the proportion of quits in the total number of separations.

Disentangling quits from layoffs on the basis of administrative data is notoriously difficult as often separations classified as under "mutual" agreements may hide actual layoffs. The above notwithstanding, data from the unemployment registers (reported in the bottom panel of Table 1), which also have the advantage of covering the very beginning of the transition process, suggest that the bulk of flows from employment to unemployment in 1991-2 was indeed represented by quits. Relatively many voluntary separations were also observed in countries which embarked later upon a structural transformation process, such as Russia. Based on an enterprise survey carried out by the World Bank, Commander et al. (1995) report that only about 25 per cent of separations from state enterprises in Russia were associated with individual or collective layoffs.

Information from the registers of jobseekers pointed to monthly inflow rates into unemployment (unemployment inflows as a proportion of the working age population) of half a percentage point in most transition countries [OECD, 1994b], compared with above one per cent in western Europe and 2-3 per cent in North America. Thus, unemployment was rising not because of the predicted large cohorts of workers being laid-off from state enterprises, but as a result of remarkably low outflow rates. Outflows from unemployment to jobs, in particular, were marginal. With the notable exception of the Czech Republic, only up to five out of one hundred jobseekers were leaving unemployment every month because they had found a job. When using administrative records (data from the unemployment register), outflows to jobs generally offer a better measure of actual exits from unemployment than total outflows. This is because exits from the unemployment registers not associated with the take-up of a job are often merely a by-product of the exhaustion of the maximum duration of benefits ${ }^{20}$. Thus, outflow to job rates of the order of 5 per cent implied that had unemployment stabilised at these levels - the average duration of unemployment would have been of the order of 20 months!

Finally, contrary to popular wisdom and the transition mechanics embedded in the models reviewed above, the ownership of enterprises did not discriminate between job creation and destruction. The bulk of net job creation was concentrated in self-employment and the new small business sector. Enterprises being privatised did not seem to behave very differently from enterprises still in state

\footnotetext{
${ }^{19}$ See OECD (1994a).

${ }^{20}$ This comes out very clearly when inspecting data from the Hungarian labour offices. There is almost a one-to-one correspondence between unemployment benefit receipt and registration at labour office for those who cannot claim social assistance (e.g., because they do not pass a means test) [Boeri and Pulay, 1998].
} 
hands, in terms of both employment and output performance [Bilsen and Könings, 1998; Könings, Lehmann and Schaffer, 1996; Richter and Schaffer, 1996] and employment-output elasticities in (large) private enterprises were comparable to those observed in the units still in state hands [Estrin and Svejnar, 1998].

Hence, while the stocks seemed to behave as anticipated, for labour market flows it was a different story. And quite a different one.

The differences between actual labour market flows and their characterisation under the OST literature can be highlighted by matched records across household surveys. By tracking the same individual over different LFS waves, it is possible to map transitions from one state in the labour market to another ${ }^{21}$. LFS data are based on a similar methodology and harmonised questionnaires across Europe, hence offering a better basis than data from the unemployment registers for crosscountry comparisons. Unfortunately, transition countries started carrying out such surveys only three to five-six years down the road of transition ${ }^{22}$, which means that available data cannot capture the early stages of transition.

With the above caveats in mind, Figure 4. characterises yearly transition probabilities (gross flows over the base-year stock of origin), estimated on the basis of the LFS carried out in Poland, the first country in the region to have introduced such a survey, in 1992-3. Similar patterns emerge by matching records across LFS waves in other Central European countries, such as the Czech and Slovak Republics and Hungary (Boeri and Bruno, 1997).

Three facts are striking. First, outflows from employment to inactivity are twice as large as flows from employment to unemployment. Second, large direct (and genuine ${ }^{23}$ ) shifts from state-sectoremployment to private-sector-employment occur which are not mediated by intervening unemployment spells: in Poland such job-to-job shifts were in 1992-3 more than twice as large as flows from public sector employment to unemployment (almost 9 per cent of state sector employment moved directly to the private sector compared with a modest 4 per cent becoming unemployed). Third, a very significant component of outflows from unemployment (more than 40 per cent!) involved withdrawals from labour force participation rather than flows to private sector employment.

Thus matched LFS records suggest that the stagnancy of unemployment pools in these countries was a by-product both of the fact that i) employment reductions were accommodated mainly via flows into inactivity and ii) significant direct shifts of workers from the state to the private sector were occurring. Needless to say, both channels of labour market adjustment are banned under the OST literature which assumes a constant labour force and focuses exclusively on flows between public and private employment mediated by intervening unemployment spells. Indeed Figure 4 looks quite different from the standard flow-chart of the OST literature (Figure 1.).

\subsection{Major Structural Change with low Worker Flows}

\footnotetext{
${ }^{21}$ A statistical problem involved by using matched records across different LFS waves is that sample attrition, nonresponse and errors in the classification of the labour market states of individuals at different points in time tend to bias results in a direction which is not predictable a priori.

${ }^{22}$ See OECD (1993) and Chernyshev (1997) for a discussion of the reform of labour market statistics in formerly planned economies.

${ }^{23}$ Workers in privatised enterprises by definition shift from the public to the private sector without experiencing unemployment spells. We removed these spurious flows by combining matched records with the retrospective information contained in the survey. In particular, we counted as yearly flows from public to private employment only workers who had tenures in the private sector shorter than 12 months.
} 
Labour markets where shifts of workers from declining (e.g., state-owned-enterprises) to expanding (private units, notably in the service sector) sectors occur without intervening unemployment spells typically generate relatively small worker flows. This is because there is just one shift rather than two. Workers go directly to the new sector, rather than moving from employment to unemployment and vice versa. Moreover, mobility is low when the two non-employment states (not only inactivity, but also unemployment) tend to become "absorbing states" of sorts where, once in, it is very difficult to get out. In spite of the radical and historically unprecedented transformation occurring in these economies, transition countries have indeed displayed remarkably low mobility of workers across labour market states, occupations and sectors.

Table 2 reports worker mobility indexes and measures of structural change for all transitional economies for which LFS data were available, for the remaining OECD countries and for Italy, the western European country typically indicated as being endowed with the most sclerotic labour market, and traditionally very low mobility of its workforce. In particular, the first four columns display summary measures of structural change, namely the standard deviation of employment growth across 9 sectors (STD), two summary measures of job reallocation ${ }^{24}$, respectively across sectors (SR) and firms of different ownership (PR) as well as the average yearly change in the share of private employment in total employment (DPS). The next two columns display scalar mobility measures for yearly transition matrices ${ }^{25}$ : such measures are bounded between 1 (maximum mobility) and zero (no mobility, i.e. each individual is in the same state as one year before).

Quite strikingly, all transitional economies display lower worker mobility than a sclerotic country like Italy. Moreover, such low mobility stands in sharp contrast with the pace of structural change in these countries: indicators of structural change across sectors and occupations are indeed consistently larger than those computed for the whole group of OECD countries. Taken together, the evidence presented in table 2. suggests that dramatic changes in the distribution of employment across sectors and by ownership type of firms have occurred in these countries with relatively low worker flows.

\subsection{Overshooting the target: the drop of employment rates}

\footnotetext{
${ }^{24}$ The two indexes, SR and PR are increasing in the pace of job reallocation across sectors and between the public and private sectors respectively. In particular, the two indexes are given by:
}

$$
S R=1-\frac{|\Delta E|}{\Delta E^{+}+\left|\Delta E^{-}\right|}, \quad \text { and } \quad P R=1-\frac{|\Delta E|}{\left|\Delta E^{P U B}\right|+\left|\Delta E^{P R I V}\right|}
$$

where $\Delta \mathrm{E}^{+}$denotes the sum of sectoral employment variations over expanding sectors and $\Delta \mathrm{E}^{-}$is the sum of employment variations across declining industries while the superscripts PUB and PRIV stand, respectively, for public sector and private sector employment. Both indexes are bounded between 0 and 1, and increasing in the extent of job reallocation from declining to expanding industries and from public to private jobs. Unlike the standard deviation measure which can take high values even when all sectors and firms of different ownership are experiencing employment declines, these two indexes isolate the extent of the job reallocation from declining to expanding units involved by the transition process.

${ }^{25}$ In particular, the scalar measure is given by the index: $\frac{(n-\operatorname{tr}(M))}{(n-1)}$ where $\mathrm{n}$ denotes the number of states (the number of rows of the transition matrix, M). As shown by Shorrock (1978), when matrices have a maximal diagonal -that is, stayer coefficients are larger than any mover coefficient --- this index is bounded between 0 and 1 , is monotonically increasing in mobility, attaches value zero only to identity matrices, and one to matrices with identical rows (hence probabilities of moving independent of the state originally occupied). All the computed matrices had a maximum diagonal, hence in our case the index satisfies the four properties listed above. 
As a result of the large flows occurring from employment and unemployment to inactivity, only partly matched by flows occurring in the opposite direction, labour supply has been significantly declining in all the countries of the region. As the former planned economies entered the 1990s with high labour force participation by western standards, notably high female participation rates, a decline in labour supply was commonly predicted at the outset of transition and even advocated as a way to prevent employment reductions in state enterprises from translating into large increases of unemployment. However, the decline in labour force participation was much stronger than anticipated.

As vividly documented by Figure 5, these countries initially had employment rates well above those of countries at comparable GDP per capita levels (at purchasing power parity). The ratio of employment to the working age population (individuals aged 15 to 64 for the purpose of crosscountry comparisons) was indeed well above the regression line (estimated over the panel of middle income countries, excluding the CEECs, and the OECD countries) which is displayed in the top panel, describing the long-run relation between degree of economic development and employment to population ratios. Seven years later, most of the former planned economies and all employment to population ratios for males had moved below the regression line (bottom panel in Figure 5.).

Significantly, the largest drop in employment rates were associated with the strongest declines in labour force participation ${ }^{26}$ (Figure 6 top panel). This suggests that the main vehicle of employment reductions were flows to inactivity, e.g. those associated with the forced retirement of working pensioners and early retirement schemes, undeclared employment or household production related to survival-oriented activities. Moreover, it was not mainly participation of women to fall: in most countries the deepest declines in participation occurred among men (Figure 6, bottom panel). The a-priori expectation was that participation of women should have been declining the most because labour supply of women is more elastic - and hence could have been more affected by real wage declines - nurseries and childcare facilities previously attached to enterprises were being dismantled thereby increasing the opportunity cost of employment and the presumption was that many women were "obliged" to work under the previous regime.

\footnotetext{
${ }^{26}$ See also Boeri, Burda and Köllö (1997) who de-compose the decline in employment rates in the shares associated with i) the growth of unemployment, ii) the increase of inactivity, and iii) the decline in demographic pressures. They find that the strongest employment declines occurred in the countries with the largest falls in inactivity.
} 


\section{Final Remarks: Identifying the Actual Policy Instruments}

The OST literature reviewed in this paper contributes to highlight non-trivial interactions between the rise of unemployment and the growth of the private sector. It also shows that, if not accompanied by appropriate policies, transition may well derail. While providing a useful framework to assess some relevant policy trade-offs (e.g., those related to the setting of unemployment benefits), this large and still developing literature, however, leaves many open questions concerning the actual transition dynamics.

The OST models do not yield the U-shaped dynamics of output experienced by some of the countries which were undergoing the most radical transformations. Some additional, and rather adhoc, assumptions are required to allow these models to replicate the transitional recession. The public/private divide does not often seem to discriminate between output expansion and contraction, between gross job creation and destruction as in the OST models.

The adjustment of labour markets during transition has also been quite different from that anticipated by this literature. In particular, it has involved stagnant unemployment pools, large flows to inactivity and strikingly low workers' mobility especially when account is made of the changes occurring in the structure of employment by sector, occupation and ownership of firms.

There are a number of puzzles of transition which are not solved by this literature. Among the issues still looking for explanations:

Why did all countries experience steep declines in output at the start of transitions?

Why did such a radical structural change occur with such low worker flows?

Why were there so many job leavers as opposed to job losers in the years of the steepest employment and output declines?

Why did private employers recruit their workers mainly from the state enterprises rather than from the large unemployment pools of these countries, which should offer the cheapest labour?

Why did so many workers, notably among the male population, leave the labour force altogether after the start of transition?

These puzzles are relevant from both a heuristic and a normative standpoint. Understanding why all this occurred can improve our knowledge of economies undergoing major structural change. Moreover, it can help us in identifying the relevant policy trade-offs and the actual degrees of freedom of policy-makers in economies in transition.

The policy trade-offs embedded in the OST literature relate mainly to the alternative between a bigbang strategy and a gradual transition process. This amounts to assuming that governments can control the pace of closure of state enterprises. However, the facts discussed in the last section of this paper suggest that separations from state sector employment were, ultimately, an endogenous variable rather than a policy instrument, as they were to a large extent the by product of voluntary choices of workers. 
It could also be argued that the key control variable posited by the OST literature - namely subsidies to state enterprises - did not look at all as a control variable. Subsidies to enterprises in these countries took mainly the form of tax arrears allowed by weak tax collection administrations or by governments fearing domino effects originated by the interlocking of banks and firms.

Thus, it is still necessary to ascertain which policy instruments, if any, can be activated by policymakers in countries shifting from one economic system to another. The generosity of nonemployment benefits is a key variable governments can rather freely adjust particularly at early stages of the transformation process - as there are no longstanding entitlements to benefits, no long transitions involving the grandfathering of existing claims, to deal with -- and one that has the potential to significantly affect the pace and characteristics of labour market adjustment. 


\section{References}

Aghion, P., and Blanchard, O., (1994) 'On the speed of transition in Central Europe', NBER Macroeconomics Annual, 283-320.

Blanchard, O., The Economics of Post-Communist Transition, (Oxford: Oxford University Press, 1997).

Boeri, T., Burda, M., and Köllö, J., (1997) Mediating the Transition: Labour Markets in Central and Eastern Europe, Economic Policy Initiative Report, n.4, Centre for Economic Policy Research.

Burda, M. (1993) Unemployment, Labor Markets and Structural Change in Eastern Europe, Economic Policy 16, 101-37.

Corricelli, F., Fiscal Constraints, Reform Strategies, and the Speed of Transition: the case of Central-eastern Europe, CEPR Working Papers, 1339 (1996).

Dewatripont, M. and Roland, G. (1992) Economic Reform and Dynamic Political Constraints, Review of Economic Studies, n.59, (703-730).

Gavin, M. (1993) Unemployment and the Economics of Gradualist Policy Reform, New York, Columbia University.

von Hagen, J. (1997), East Germany, in Desai, P. (ed.) Going Global: Transition from Plan to Market in the World Economy, MIT Press, 173-207.

Konings, J., Lehmann, H. and Schaffer, M. (1996) Job creation and job destruction in a transition economy: Ownership, firm size and gross job flows in Polish manufacturing 1988-91, Labour Economics, (299-317).

McAuley, A. (1991) The Economic Transition in Eastern Europe: Employment, Income Distribution, and the Social Security Net, Oxford Review of Economic Policy, vol. 7, n.4, 93-105.

Przeworski, A. (1993), Economic Reforms, Public Opinion and Political Institutions, in L.C. Bresser Pereira et al. , Economic reforms in New Democracies, New York, Cambridge University Press.

Rodrik, D., 1995, The dynamics of political support for reforms in economies of transition, CEPR Discussion Paper, n. 1115, London, Centre for Economic Policy Research. 
Table 1 Job Losers and Job Leavers at the Early Stages of Transition

\begin{tabular}{lccr}
\hline Country & Dates & Job leavers & Job losers \\
\hline $\begin{array}{l}\text { Labour Force Survey data }{ }^{a} \\
\text { (as a \% of employment) }\end{array}$ & & & \\
Czech Republic & Q2 1993 & 2.1 & 1.5 \\
Hungary & Q2 1992 & 0.8 & 4.5 \\
Poland & Q2 1992 & 1.4 & 2.0 \\
Slovak Republic & Q1 1994 & 2.6 & 4.3 \\
Italy & $1993-94$ & 0.4 & 2.3 \\
USA & $1991-92$ & 0.9 & 3.1 \\
EU weighted average & $1991-95$ & 1.2 & 3.2 \\
\hline
\end{tabular}

Data from the unemployment registers ${ }^{b}$

(as a \% of total separations)

Czech Republic

1991-92

72.1

27.4

Poland

$1991-92$

65.7

34.3

Slovak Republic

$1991-92$

79.2

20.9

\footnotetext{
a Non-employed for less than 6 months with previous work experience by reason of termination of their previous contract as a percentage of LFS employment.

${ }^{\mathrm{b}}$ Registered unemployed for less than 12 months with previous work experience by reason of termination of their previous contract as a percentage of total inflows from employment into registered unemployment.

Sources: For the CEECs, our estimates based on individual LFS and unemployment register data; OECD, Employment Outlook, 1997 for data on Italy, US and the EU.
} 
Table 2 Structural Change and Labour Mobility (average yearly measures)

\begin{tabular}{|c|c|c|c|c|c|c|c|}
\hline \multirow[t]{2}{*}{ Country } & \multirow[t]{2}{*}{ Year } & \multicolumn{4}{|c|}{ Measures of Structural Change } & \multicolumn{2}{|c|}{ Workers' Mobility } \\
\hline & & STD $^{\mathrm{a}}$ & $S R^{b}$ & $\mathrm{PR}^{\mathrm{c}}$ & $\Delta P S^{d}$ & $\begin{array}{l}\text { Across } \\
\text { Sectors }^{e}\end{array}$ & $\begin{array}{l}\text { Across } \\
\text { States }^{\dagger}\end{array}$ \\
\hline Bulgaria $^{g}$ & $1991-7$ & 5.5 & 0.43 & 0.56 & 0.52 & $\ldots$ & $\ldots$ \\
\hline Czech Republic & $1991-7$ & 11.0 & 0.72 & 0.78 & 0.74 & 0.08 & $\ldots$ \\
\hline Hungary & $1991-7$ & 9.1 & 0.50 & 0.66 & 0.68 & 0.04 & 0.08 \\
\hline Poland & $1990-7$ & 11.5 & 0.64 & 0.66 & 0.46 & 0.15 & 0.16 \\
\hline Romania & $1991-7$ & 10.3 & 0.45 & 0.85 & 0.49 & 0.16 & $\ldots$ \\
\hline Slovak Republic & $1991-7$ & 13.5 & 0.66 & 0.67 & 0.74 & $\cdots$ & 0.08 \\
\hline Slovenia & $1993-7$ & 13.1 & 0.73 & $\ldots$ & 0.65 & $\ldots$ & $\ldots$ \\
\hline Other OECD ${ }^{h}$ & $1990-6$ & 1.7 & 0.33 & 0.09 & 0.02 & 0.16 & 0.17 \\
\hline
\end{tabular}

\footnotetext{
a Standard deviation of employment growth rates across 9 sectors (average of yearly standard deviations).

${ }^{b}$ Sectoral Reallocation index calculated over gross employment variations in 9 sectors; see the text for details. OECD data 1990-93.

${ }^{\mathrm{c}}$ Privatisation Reallocation index calculated over gross employment variations in the public and private sectors; see the text for details. Czech Republic, Hungary and Romania 1991-93.

${ }^{d}$ Average yearly change in the share of private employment in total employment, 1988-1997. Bulgaria 1990-97; Romania 1989-98; Slovenia 1994-97, share of firms privatized used instead. OECD displays data for USA.

${ }^{\mathrm{e}}$ Mobility measure for transition matrix across 9 sectors (plus unemployment and inactivity); see the text for details. Romania data based on 6 status matrix ( 5 main sectors plus non-employed): the one-year index is computed on the basis of the 1993-1995 transition matrix, assuming a Markovian process.

${ }^{f}$ Mobility measure for transition matrix between the public and the private sectors (plus unemployment and inactivity); see text for details.

${ }^{9}$ STDV calculated for 6 sectors only, 1990-96. SR calculated for 1991-93.

h Workers' Mobility indexes display data computed for Italy only.
}

Notes $\ldots$ = not available.

Sources Individual data from National Labour Force Surveys for Central and Eastern Europe; OECD, Labour Force Surveys, for the OECD countries. T. Boeri and C. Flinn (1999). 
Figure 1 Labour Market Flows in the Optimal Speed of Transition Literature

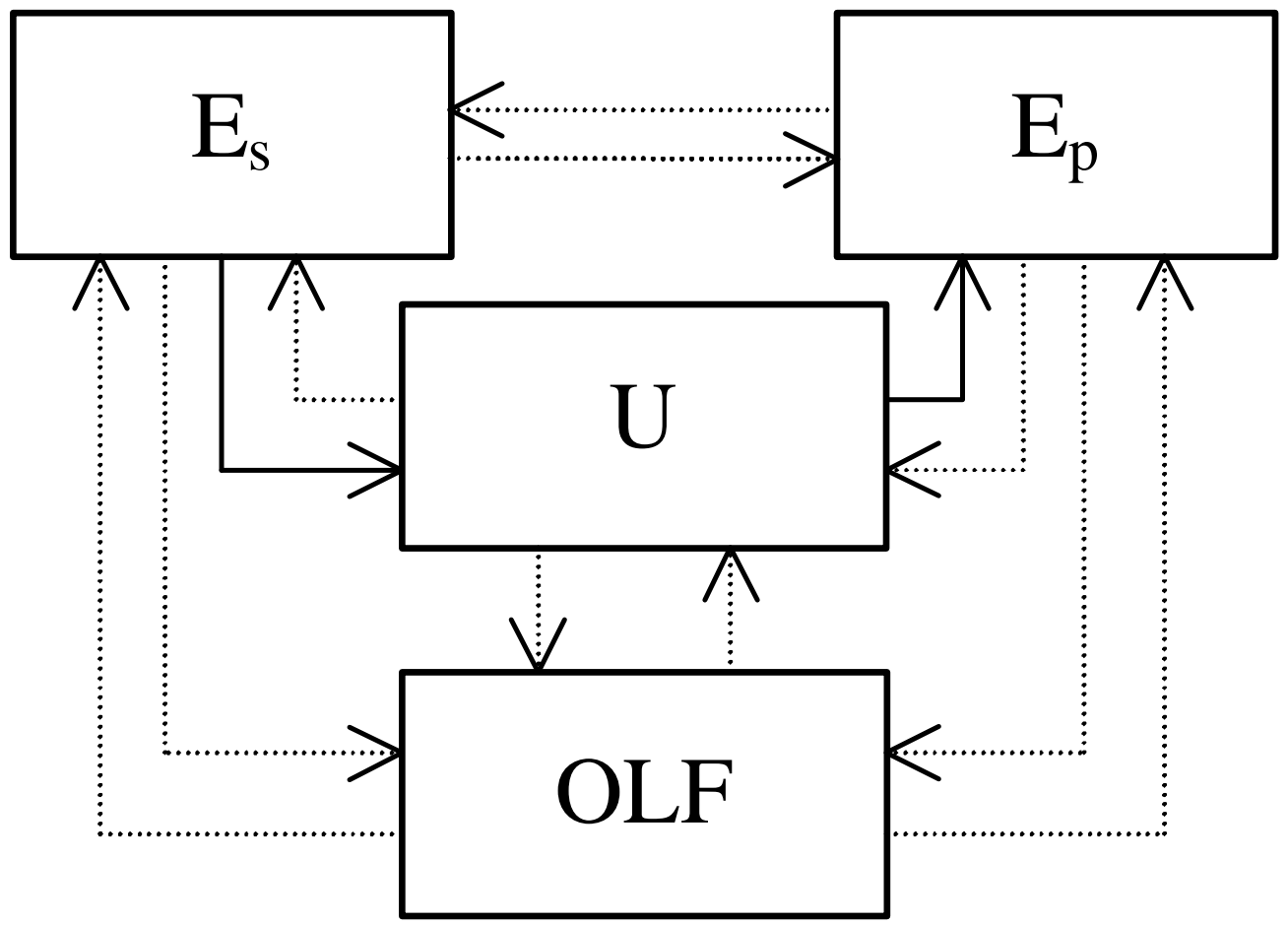

allowed

not allowed

Notes: $E_{S}=$ employment in state firms

$E_{p}=$ employment in private firms

$\mathrm{U}=$ unemployment

OLF $=$ out-of-the labour force 
Figure 2

Figure 2a GDP Decline by Transitional Years

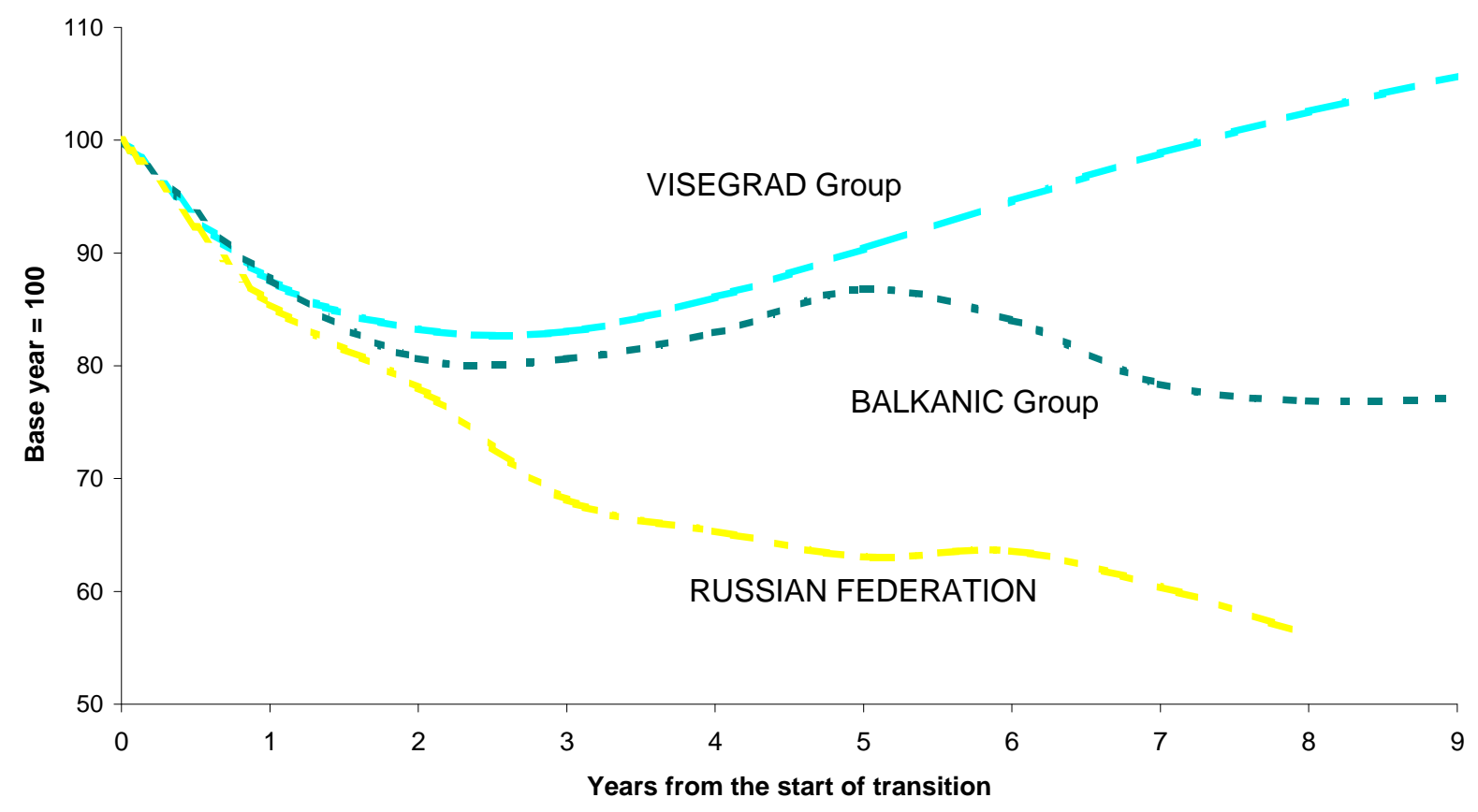

Figure 2b Industrial Production Decline by Transitional Years

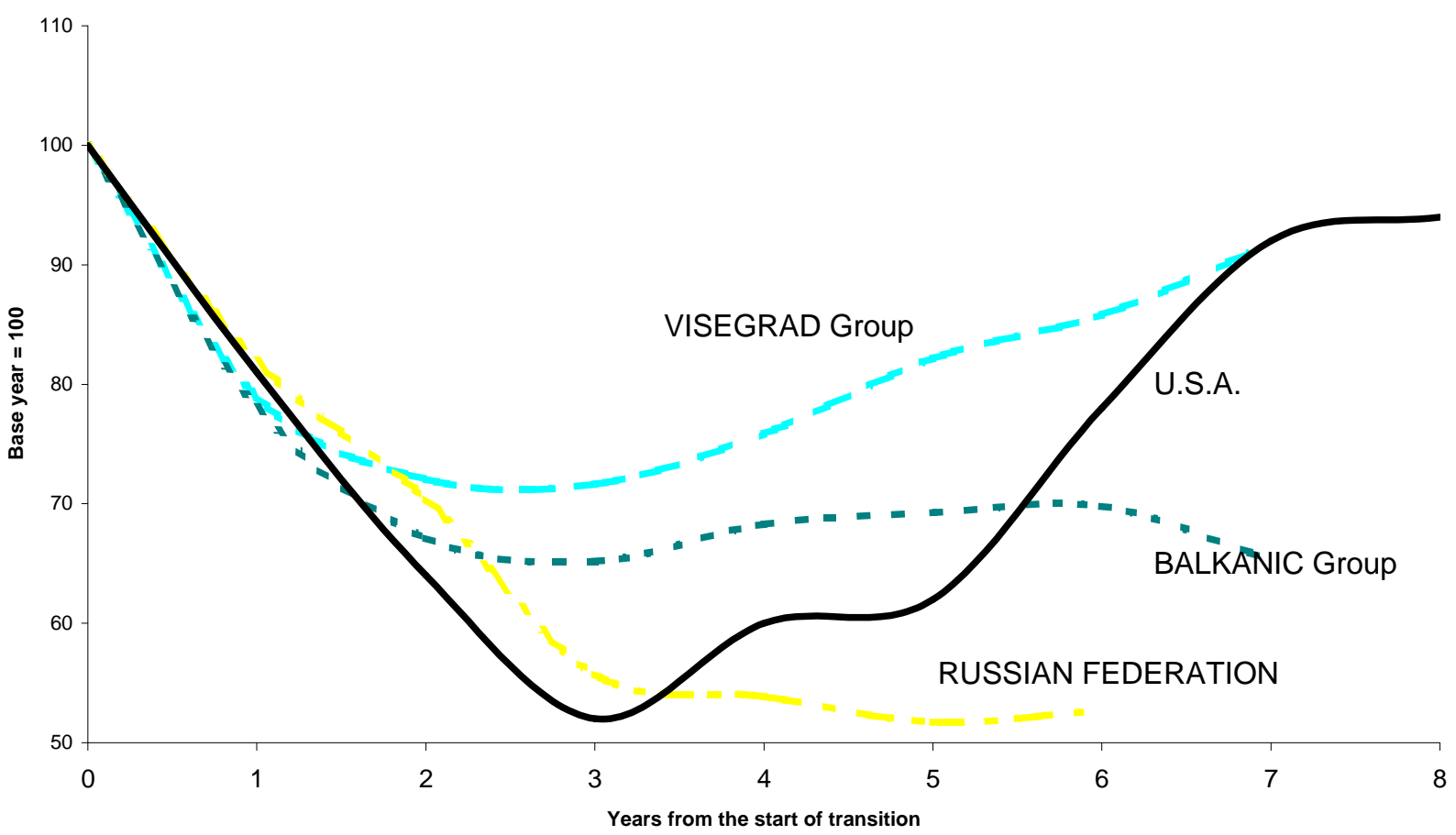

Note: Visegrad Group includes Czech Republic, Hungary, Poland and Slovak Republic. Balkanic Group includes Bulgaria and Romania. USA data refer to the 1929-37 period.

Source: OECD, Short Term Indicators and EBRD Transition Report. 
Figure 3 Projecting the Transition

(based on Poland 1989-91 experience)

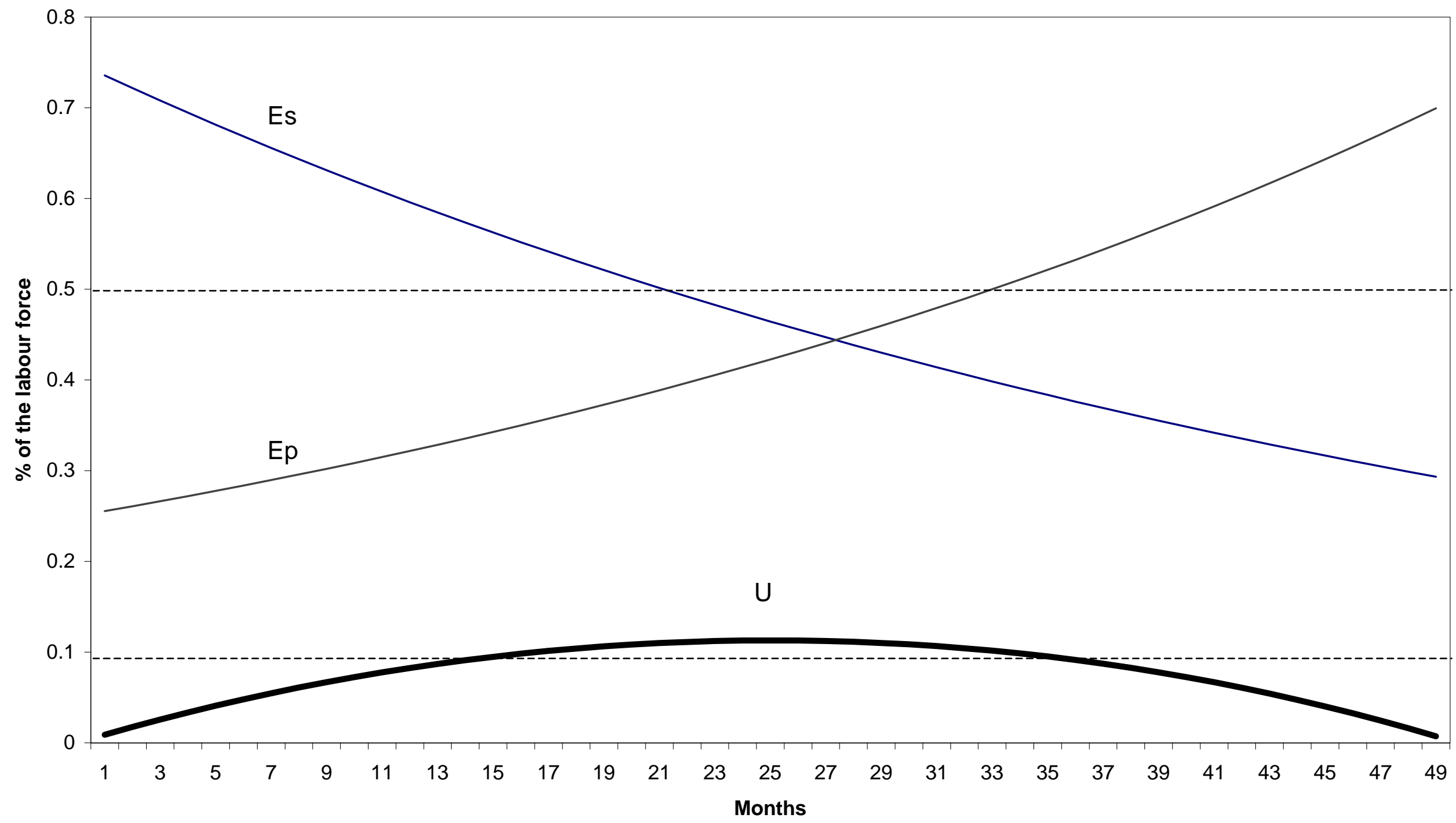

Note: Simulation of the mechanic model based on the following initial conditions and values of parameters: $E s(0)=0.75 ; E p(0)=0.25 ; U(0)=0 ; s=0.019$ and $g=0.021$. $\mathrm{Es}=\mathrm{employment}$ in state sector, $\mathrm{Ep}=$ employment in private sector, $\mathrm{U}=$ unemployment. 
Figure 4 Yearly labour market flows in Poland 1992-1993 (LFS)

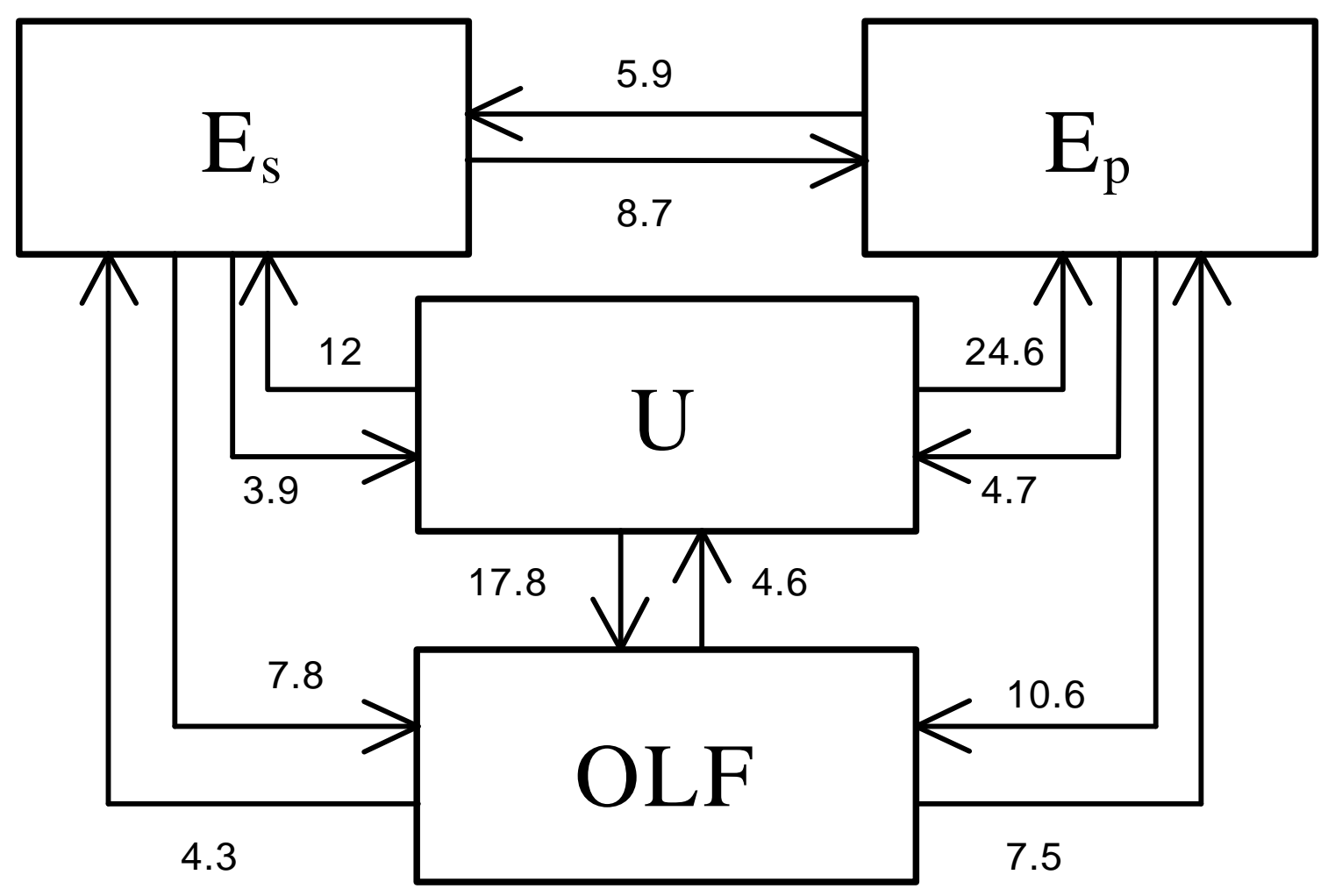

Note: Numbers in the chart denote estimated flows as a percentage of the population of origin. Source: Boeri and Bruno, 1997: matched records across quarterly LFS waves. 
Figure 5

Economic growth and employment rates ${ }^{a}$

(Middle-income and OECD countries, 1990)

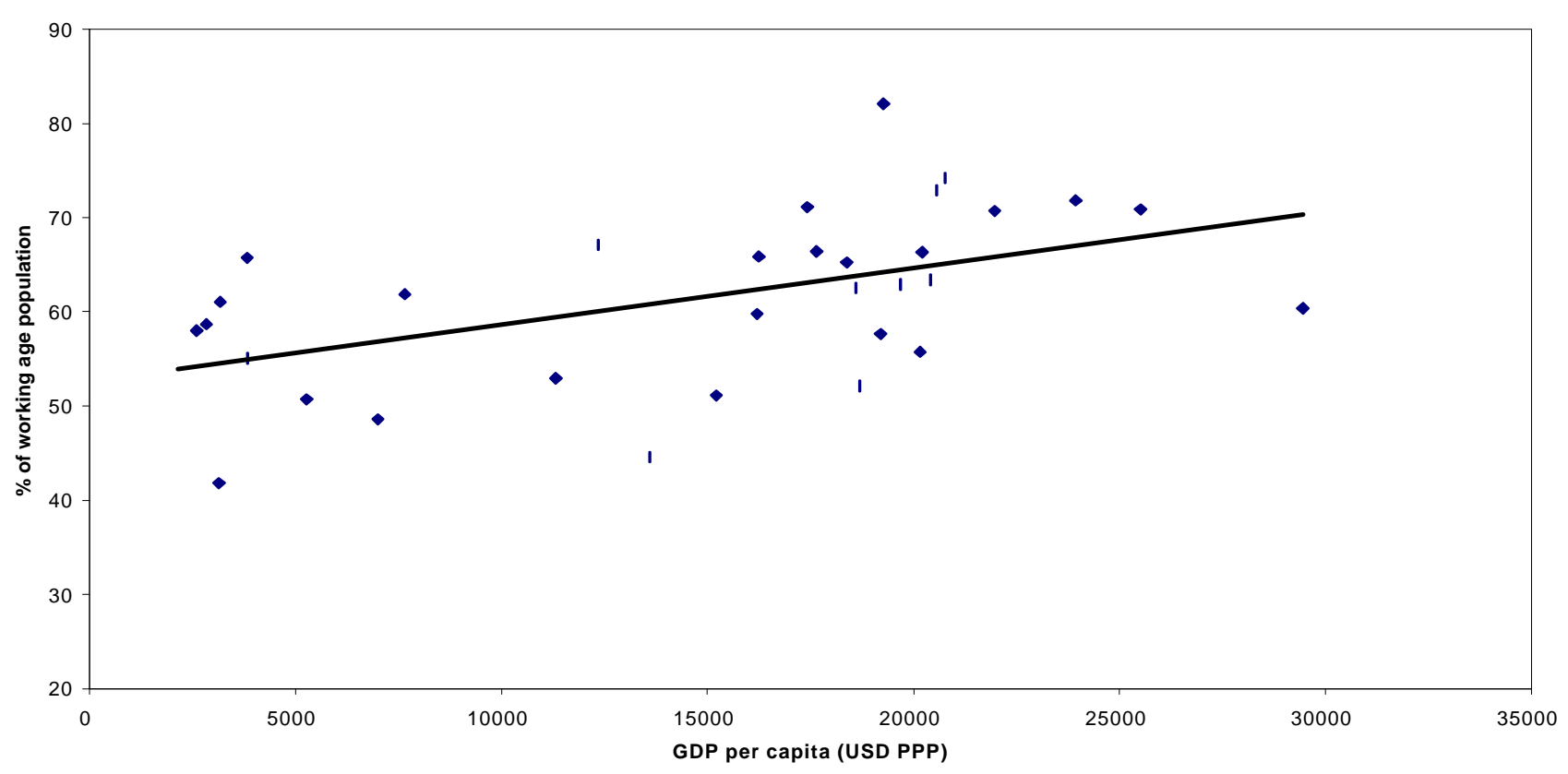

Overshooting the decline in Employment Rates

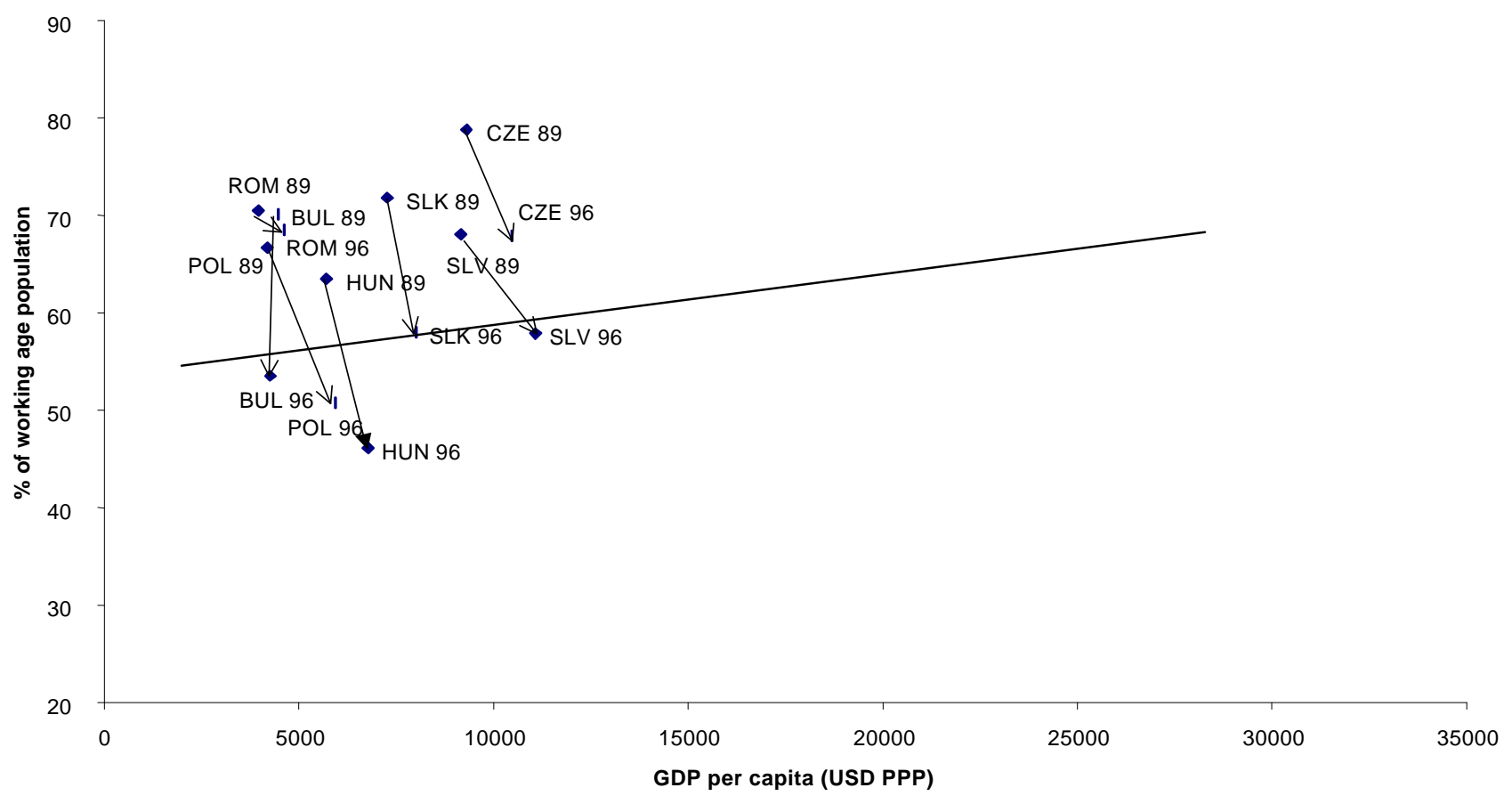

${ }^{\text {a }}$ Estimated equation: $\mathrm{ER}=52,59+0,006 * \mathrm{GDP}$ pc $\quad \mathrm{R}^{2}=0,25$

Source: OCDE Labour Market Database, World Development Tables, from the OECD National Accounts Report. 
Fig 6a Dis-Employment and decline in participation (1989-1996)

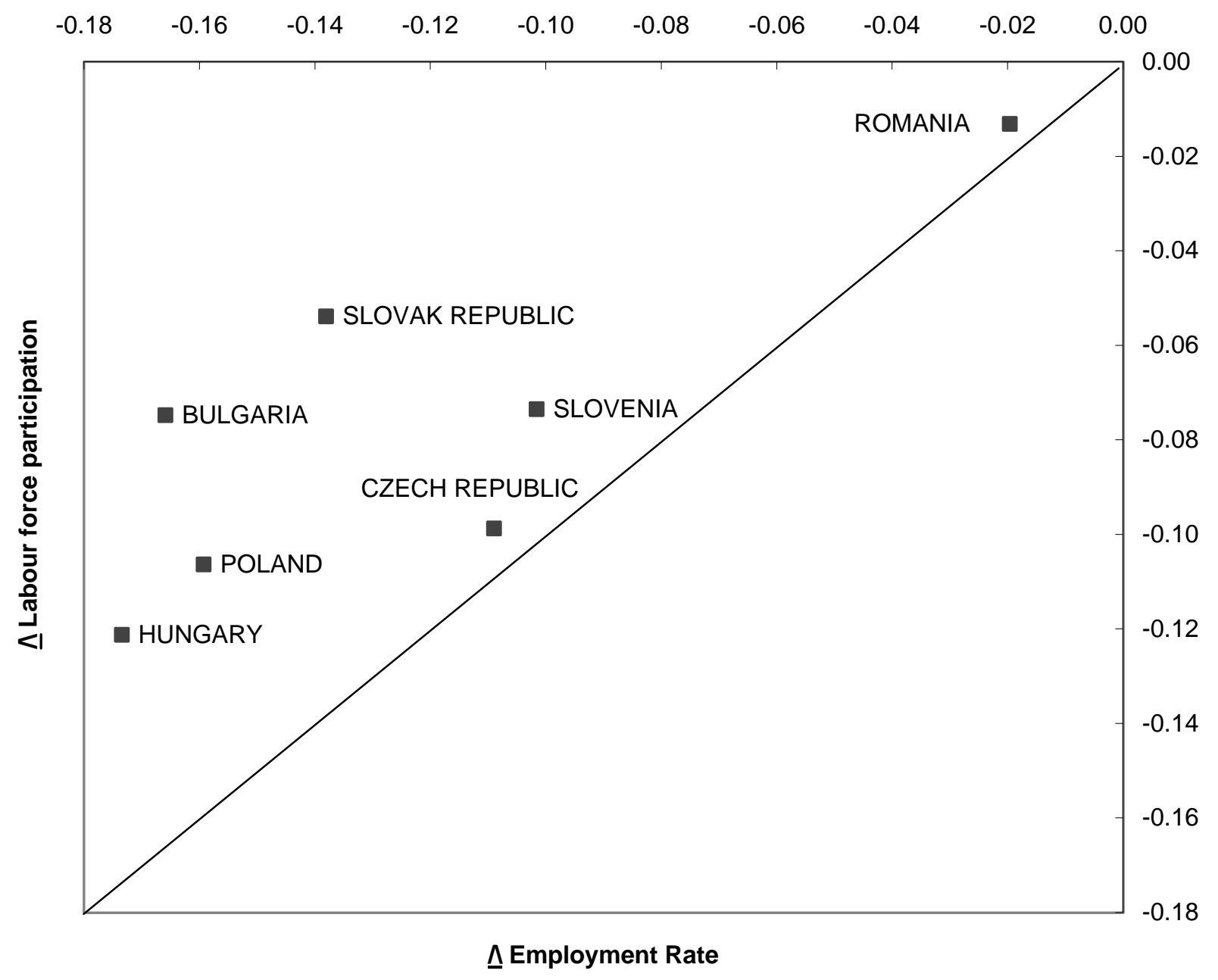


Figure 6b Not only females out of the labour market

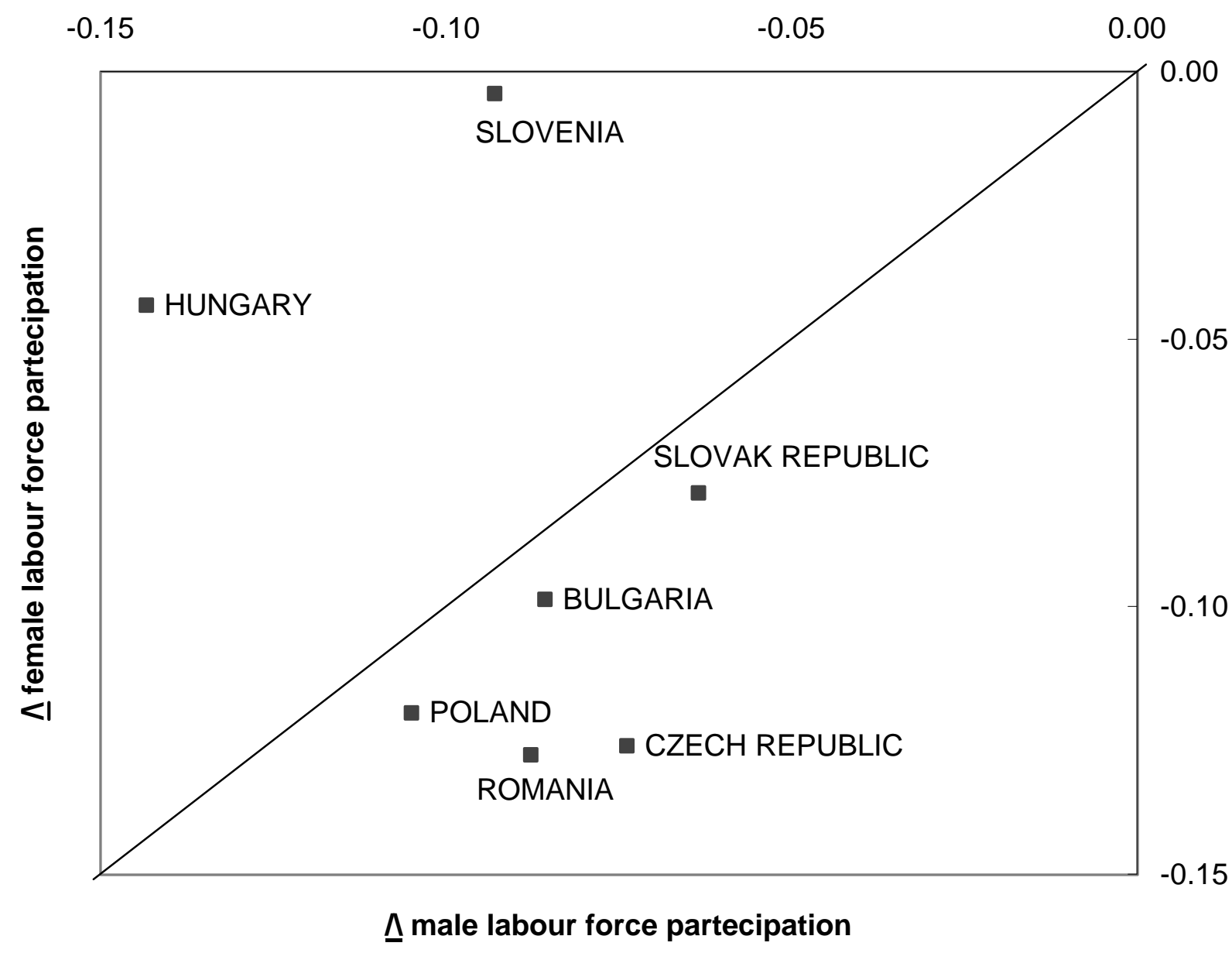




\section{Annex}

\section{Building Blocks of the OST Models}

\section{a) The Scale Effects}

A key assumption of this literature is that the labour force is fixed to some constant $\bar{L}$. Thus, the sum of employment in the public sector $\left(\mathrm{E}_{s}\right)$, employment in the private sector $\left(\mathrm{E}_{p}\right)$ and unemployment $(\mathrm{U})$ can be conveniently normalised to one unit:

$$
E_{s}(t)+E_{p}(t)+U(t)=\bar{L}=1
$$

A mechanic model like that outlined in Chapter One is a useful starting point insofar as it highlights the role played by scale effects in the rise of unemployment. In continuous-time this mechanic model of transition can be rewritten as follows:

$$
E_{s}(t)=E_{s}(0)^{-s t}
$$

where "s" denotes, as usual, the pace of closure of state sector jobs, and:

$$
E_{p}(t)=E_{p}(0) e^{g t}
$$

where " $\mathrm{g}$ " is the (instantaneous) rate at which new jobs are created in the private sector. It follows that unemployment evolves according to:

$$
U(t)=1-E_{s}(0) e^{-s t}-E_{p}(0) e^{g t}
$$

The scale effects generate a hump-shaped dynamics of unemployment. In particular, when $g$ $=\mathrm{s}:$

$$
\frac{d U}{d t}=s\left[E_{s}(t)-E_{p}(t)\right]
$$

that is, unemployment grows until employment in the private sector is as large as employment in the state enterprises. After the locus where $\mathrm{E}_{s}=\mathrm{E}_{p}$ is reached, unemployment starts declining.

\section{b) Endogenous Job Creation}

There is no economics in the model sketched above as the dynamics of unemployment is entirely driven by mechanical factors, that is, pure scale effects. In order to assume away scale effects and focus only on economics, let us define gross job creation and destruction in terms of flows only, i.e.:

$$
\frac{d E_{s}(t)}{d t}=-s(t)
$$

and

$$
\frac{d E_{p}(t)}{d t}=g(t)
$$

from which it follows that:

$$
\frac{d U(t)}{d t}=s(t)-g(t)
$$

Next we endogenise job creation. Along we Aghion and Blanchard (1994) (AB for short), we will assume that (private) job creation footnote is governed by:

$$
g(t)=(1-e)(1+\vartheta-w(t)-\tau(t))
$$

where $0<e<1$ are entry barriers, $\vartheta$ is the productivity differential between the public and the private sectors, whilst $w$ is the (efficiency) wage in the private sector and $\tau$ is a (flat) tax per worker in both public and private enterprises earmarked to the financing of unemployment benefits footnote. In the $\mathrm{AB}$ model, private employers recruit only from the unemployment ranks and pay a premium over the reservation wage of the unemployed, that is, the 
unemployment benefit, $b$. Such a premium can be rationalised either as an incentive device to prevent shirking - e.g., a no-shirking condition, à-la Shapiro-Stiglitz (1984) - or, alternatively, as a way to increase the workers' loyalty to the firm, that is, a "gift-exchange" as in Akerlof (1982). Whatever the interpretation for this premium, private wages should be as high as to ensure that the value of being employed in the private sector $\left(\mathrm{V}_{p}\right)$ exceeds the value of being unemployed, $\mathrm{V}_{u}$, by some (exogenous) amount, $\mathrm{c}$ :

$$
V_{p}(t)-V_{u}(t)=c
$$

Using then the two asset value conditions for employment in the private sector and unemployment footnote, respectively, one obtains that:

$$
w(t)=b+c\left(r+\frac{g(t)}{U(t)}\right)
$$

where $r$ is the discount rate and the last term within brackets denotes hirings over the unemployment stock, that is, job finding probabilities of the unemployed in this model. Thus, the premium over unemployment benefits should be larger the higher the wedge between the value of being employed in the private sector and the value of unemployment, the rate at which workers discount future earnings and the probability of being hired once lost a job. Equation (1.8) also shows that unemployment exerts moderating effects on wage setting, which in turn, by (1.6), implies that unemployment boosts job creation in the private sector.

However, there is also a feedback mechanism operating from the fiscal side in $\mathrm{AB}$ model which counteracts the effects of unemployment on job creation via wages, namely the financing of unemployment benefits and associated pressures on unit labour costs. Unemployment benefits are indeed entirely funded out of labour taxation. The budget constraint is therefore given by:

$$
\tau(t)(1-U(t))=b U(t)
$$

hence the tax rate clearing the Government budget is given by:

$$
\tau(t)=\frac{b U(t)}{\left(E_{s}(t)+E_{p}(t)\right)}
$$

This, together with (1.6), implies that too high unemployment may also negatively affect private job creation because of the burden on enterprises associated to paying unemployment benefits. This fiscal externality clearly becomes less stringent if deficit financing is allowed for, e.g. , by simply adding a new term (d) on the right-hand-side of (1.9) as in Coricelli (1996).

Due to the presence of the fiscal externality, there is a maximum speed at which public sector jobs can be destroyed. Above this critical level of s, say s*, transition does not take off as private employers are buried under too heavy labour taxation. Moreover, for values of s lower than $\mathrm{s}^{*}$, there can be two equilibria: a low-unemployment equilibrium, like (U1) and a high-unemployment equilibrium (U2) as in Figure I.I. When private employers have static expectations, from any point to the left of $\mathrm{U} 2$ only $\mathrm{U} 1 \mathrm{can}$ be attained while if unemployment exceeds U2, social security contributions are so high that the private sector grows too slowly to prevent a rise of unemployment or does not take off at all. Thus, the bad equilibrium, U2, is unstable. When private employers are forward-looking (which amounts to adding expected changes in the value of private sector jobs on the right-hand-side of (1.6) the economy may settle down at both equilibria. The optimism or pessimism of employers becomes a self-fulfilling prophecy as high job creation reduces labour taxation and vice versa. This holds even when deficit financing is allowed for.

\section{(insert Figure I.I. about here)}

\section{c) Endogenous Job Destruction}

The next step is to endogenise job destruction. In these models separations are entirely demand-driven and dictated by restructuring plans of state enterprises. The latter depend on the extent of employment reductions required to bridge the productivity gap with the private sector. Let $\mathrm{f}\left(\mathrm{E}_{s}\right)$ denote the production function of state enterprises. It is assumed that at the start of 
transition everybody is employed in state enterprises footnote and labour productivity therein equals one unit, that is:

$$
f(1)=1
$$

State enterprises are overmanned footnote : the restructuring of state enterprises requires that a proportion $(1-\lambda)$ of the workforce be fired, where $\lambda$ solves:

$$
\frac{f(\lambda)}{\lambda}=1+\vartheta
$$

that is, restructuring makes state firms as productive as private firms. State enterprises are assumed to be controlled by insiders who can block privatisation-cum-restructuring plans [Frydman and Rapaczynski, 1994]. All workers of state enterprises are (ex-ante) homogeneous and hence, in the case of restructuring, face the same probability of dismissal, 1- $\lambda$. It follows that restructuring can start only if:

$$
V_{s} \leq \lambda V_{p}+(1-\lambda) V_{u}
$$

where $\mathrm{V}_{s}$ is the value of being employed in the state sector, $\mathrm{V}_{p}$ the value of being in the private sector and $\mathrm{V}_{u}$ the value of being unemployed. In other words, the expected value of the status quo should be lower than the expected value of restructuring. As the value of non-employment is always lower than the value of employment (either public or private) in these models, when (1.13) is not satisfied, managers should be selective in their dismissal policies and exert a "divide-and-rule" strategy [Dewatripont and Roland, 1992] in order to convince their workforce to accept the restructuring.

As both $\mathrm{V}_{p}$ and $\mathrm{V}_{u}$ decrease with the size of the unemployment pool (the former because of the fiscal externality and the latter because job finding probabilities of the unemployed decline) it follows that there is a critical value of $U$ (say $U^{*}$ ) above which restructuring (transition) does not take-off or is blocked by insiders. Below $\mathrm{U}^{*}$, transition starts and involves increasing unemployment until $\mathrm{U}^{*}$ is reached. If the initial shock to state sector employment is too large, however, reductions in unemployment are required to set in motion the restructuring process. This is, in essence, the additional feedback mechanism introduced in the model, coming from the opposition of state sector workers to restructuring.

\section{d) The Balanced Path footnote}

Normalising $r V_{s}$ to equal one unit, and taking into account (1.7) and the definitions for the value of being employed in the private and unemployed, we can rewrite (1.13) as follows:

$$
1 \leq \lambda w+(1-\lambda))(w-c r)
$$

and when the above condition holds has an equality (when we are along the balanced path):

$$
w=1+(1-\lambda) c r
$$

which states that there should be a wedge (increasing in the probability of dismissal footnote ) between the wage paid in the private and in the state sector in order to induce workers to accept restructuring.

We can finally solve for the equilibrium level of unemployment satisfying (1.14). First, we equate (1.14) to the wage setting equation (8). Next we substitute in this expression the job creation equation (1.6) (leaving aside, for simplicity, the fiscal externality effect) and solve for $\mathrm{U}$ obtaining:

$$
U^{*}=c(1-e) \frac{(\theta-(1-\lambda) c r)}{(1-b-\lambda c r)}
$$

The equilibrium speed of transition, $\mathrm{s}^{*}$, will be such as to maintain unemployment at $\mathrm{U}^{*}$. In other words, $\mathrm{s}$ should be as large as to equate unemployment inflows (s times the proportion of workers to be laid-off) to outflows when $\mathrm{U}=\mathrm{U}^{*}$. Equating then private job creation (1.6) to $s(1-\lambda)$, when (14) is satisfied, one obtains: 


$$
s^{*} \lambda=(1-e)(\vartheta-(1-\lambda) c r)
$$

which shows that the equilibrium speed is increasing in the productivity gap and decreasing in entry barriers (exogenous obstacles to gross job creation) and the efficiency wage premium.

Notice that by (1.15), equilibrium unemployment is increasing in unemployment benefits. However, too low benefits may prevent the start of transition especially when the costs of unemployment benefits is only partly internalised by firms (e.g., benefits are paid out of general fiscal revenues footnote, private firms are de facto exempted from social security contributions e.g., due to weak tax enforcement - or Governments receive a gift like foreign loans at concessional terms to pay benefits). When the Government budget constraint (1.9) is not binding, higher benefits increase the asset value of unemployment and hence reduce the opposition of insiders to restructuring. We have indeed that:

$$
\frac{\partial V_{u}}{\partial b}=\frac{1}{1+r}\left[1-\frac{c r(1-e)}{U+c}\right]
$$

which shows that, on the one hand, higher benefits increase the instantaneous value of unemployment, but, on the other hand, reduce the job-finding probability of those without a job. This second effect tends to dominate the effect of benefits on the instantaneous utility when benefits are entirely funded via payroll taxation. In the latter case we find indeed that:

$$
\frac{\partial V_{u}}{\partial b}=\frac{1}{(1+r)(U+c)(1-U)}[(U+c)(1-U)-\operatorname{cr}(1-e)]
$$

which becomes negative for large $\mathrm{U}$.

Overall, insofar as benefits can be financed without increasing payroll taxes, high unemployment benefits reduce the resistance of insiders to restructuring and permit the take-off of transition. This is the standard result of the OST literature. However, when higher benefits imply heavier taxation of labour in the private sector, the negative effects of benefits on job generation in the private sector tend to dominate, as the transition proceeds, those on the (instantaneous) welfare of the unemployed. From this point onward it is better to reduce unemployment benefits to ease restructuring. In order words, the optimal sequence is "high" benefits followed by "low" benefits. 
Figure I.I

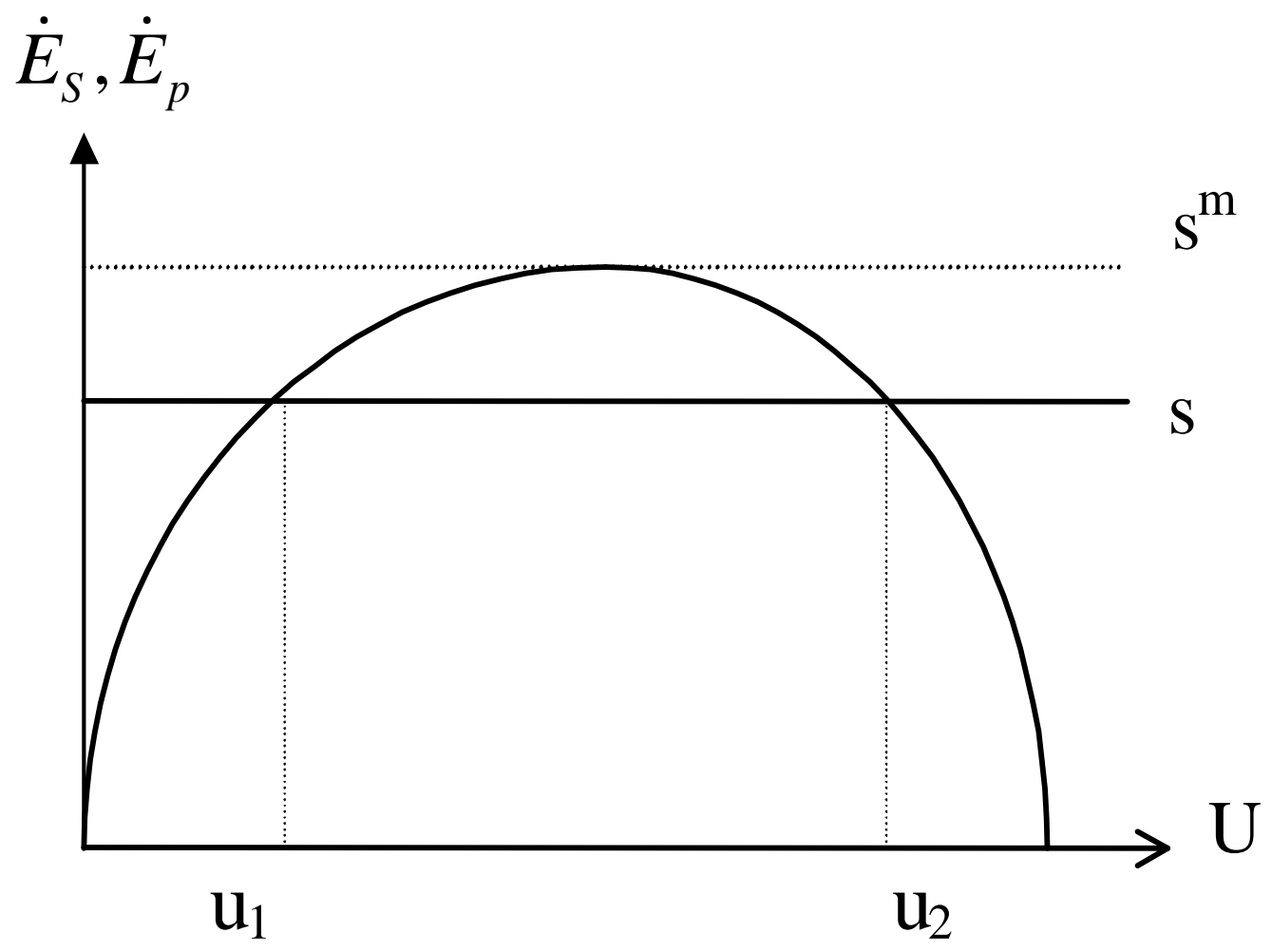

